\title{
Rekomendasi untuk Situs Web DMO (Destination Management Organization) Wonderful Indonesia Berdasarkan Dimensi Informasi pada Model ICTRT
}

\author{
I Putu Sudhyana Mecha' \\ 'D-IV Tourism Business Management \\ Politeknik Negeri Banyuwangi \\ sudhyanamecha@poliwangi.ac.id
}

\begin{abstract}
Website is one kind of information media that can be used as intermediaries of tourism information. Related to that matter, Wonderful Indonesia tourism website has an important role as national-level DMO (Destination Management Organization). However, it has not been recognized yet as something important in term of tourism, especially when viewed from information dimension. Therefore, evaluation based on IPA (Importance-Performance Analysis) was carried out in order to arrange recommendation for Wonderful Indonesia tourism website. Sampling was conducted to travel agencies from ASITA (Association of Indonesian Tours \& Travel Agencies) Bali, as the representative of tourism practitioners. Moreover, considering their role as intermediaries between tourism information and the tourists. Based on the results of evaluation, there were two indicators, such as accommodation information and local weather information that needed to be paid more attention. Regarding the evaluation above, further interviews were also conducted in order to get crosscheck feedback, so it can be more convincing as recommendation. The interview was based on the experts that coming from government, practitioner, and academics related to tourism as stakeholders, so the recommendation for Wonderful Indonesia website is expected to be proper use according to the needs of users of tourism information
\end{abstract}

Keywords: website, tourism information, destination management organization, Wonderful Indonesia 


\section{Pendahuluan}

Teknologi informasi (TI) telah berkembang pesat dan semakin mengglobal. Keberadaan internet serta semakin canggihnya perangkat pintar seperti personal computer (PC), laptop, tablet PC, dan smartphone menjadikan seluruh dunia terhubung satu sama lain. Internet of Things, Cloud Computing, Virtual Reality, Big Data, dan Social Media barangkali hanya sedikit dari sekian banyak fenomena teknologi informasi (TI) yang sedang ramai diperbincangkan (Lytras, 2015 dalam Mecha, Wiranatha, \& Sudiarta, 2019). Mengingat bahwa TI selalu tumbuh dan berkembang, maka bukan mustahil jika dari situ lahir teknologi baru yang mampu menggantikan pendahulunya sekaligus menciptakan fenomena yang berbeda dengan sebelumnya. Hal ini sesuai dengan fenomena yang sedang terjadi saat ini, yaitu revolusi industri 4.0 , dimana hampir semua bidang pekerjaan maupun industri mengalami perubahan, tidak terkecuali pariwisata.

Secara umum, revolusi industri 4.0 merujuk pada transformasi sistemik yang berdampak pada masyarakat, struktur pemerintahan, serta identitas orangorang, selain pengaruhnya pada ekonomi dan manufaktur (Sung, 2018). Istilah revolusi industri dapat diuraikan secara singkat sebagai berikut. Revolusi industri 1.0 ditandai dengan mekanisme produksi dengan tenaga air serta panas; revolusi industri 2.0 ditandai dengan produksi besar-besaran dengan bantuan tenaga listrik, dan kemudian diikuti dengan kemunculan revolusi digital yang bisa dilihat dari adanya media elektronik serta TI dalam rangka menciptakan produksi otomatis (Schwab, 2016 dalam Sung, 2017). Lebih lanjut, revolusi industri 4.0 yang terjadi saat ini merupakan perkembangan dari revolusi industri yang telah terjadi sebelumnya, dimana pada era ini peranan $\mathrm{Tl}$ benarbenar merubah cara kerja serta praktik bisnis berbagai sektor industri. Itu artinya, keberadaan informasi menjadi penting dan patut diperhatikan, terutama jika terkait dengan bagaimana value dari suatu produk baik barang ataupun jasa diterjemahkan kepada konsumen. Dengan kata lain, TI bisa dikatakan berkontribusi besar terhadap perubahan yang terjadi dalam praktik bisnis dan strateginya, demikian pula dengan struktur industri yang ada (Buhalis \& Law, 2008).

Pariwisata turut mengalami perubahan dalam praktik bisnisnya. Salah satu indikasinya adalah bagaimana cara orang-orang sekarang dalam mengakses informasi, terutama yang terkait dengan pariwisata. Dahulu, orang-orang ketika hendak berwisata biasanya mengetahui informasi melalui media cetak seperti broser, pamflet, note, dan lain-lain. Selain itu, mereka juga proaktif mencari informasi melalui pihak ketiga, seperti travel agent maupun pihak lainnya. Sangat berbeda dengan keadaan saat ini, sebagaimana telah disebutkan sebelumnya bahwa segala informasi dapat diakses secara daring (online). Dengan kata lain, praktik bisnisnya berubah dari yang dulunya paper menjadi paperless. Hal tersebut didukung pula dengan makin menguatnya kebutuhan akan informasi, ditambah dengan kondisi yang menuntut segalanya serba cepat dan tepat. Tidak salah memang apabila akses informasi secara daring (online) menjadi pilihan yang terbaik, karena sumber informasi daring, terutama yang erat kaitannya dengan pariwisata telah teruji berdasarkan analisis faktor berikut, yaitu accessibility, security, information-trust, 
interaction, dan personalization (No \& Kim, 2015).

Penggunaan istilah ekosistem dapat digunakan sebagai analogi untuk menggambarkan bagaimana peranan $\mathrm{TI}$ dalam pariwisata. Ekosistem, menurut ilmu alam dapat diartikan sebagai suatu jaringan interaksi antara sesama organisme hidup dan non-hidup, maupun lingkungannya (Tansley, 1935 dalam Benckendorff dkk., 2014). Poin penting dari adanya ekosistem adalah bagaimana organisme mampu berubah dan beradaptasi berdasarkan interaksi timbal-balik yang dilakukan antara individu dengan lingkungannya, demikian pula halnya dengan segala macam entitas yang terdapat dalam ekosistem digital, atau dalam kasus pariwisata disebut dengan istilah ekosistem pariwisata digital. Salah satu penerapan ekosistem pariwisata digital dapat dilihat dari bagaimana peranan Destination Management Organization (DMO) dalam rangka menyalurkan informasi mengenai destinasi pariwisata. Keberadaan situs web DMO mempunyai fungsi ganda dalam kaitannya dengan promoting maupun managing, sehingga sering disebut juga dengan istilah Destination Management System (DMS), atau virtual networks in tourism (Lytras dkk., 2010).

Peranan situs web sebagai sumber informasi pariwisata sudah terlihat secara nyata, terutama dalam kaitannya dengan strategi pemasaran via daring, mengingat konsumen atau wisatawan telah menggunakan internet untuk memilih destinasi wisata yang dikehendaki atau dalam meningkatkan pengalaman berwisatanya (Yannacopoulos dkk., 2014). Konsep lainnya, yaitu manajemen destinasi menyatakan bahwa DMO memiliki banyak peran, dimana tidak hanya sebatas pada promosi dan manajemen destinasi saja, tetapi juga telah mampu mempengaruhi pengambilan keputusan wisatawan terkait pilihan destinasi yang hendak dikunjungi (Benckendorff dkk., 2014). Situs web sudah mampu berperan sebagai atribut pendukung destinasi, seperti yang sudah terlihat pada situs web negara-negara bagian Amerika Serikat, seperti New York City, Los Angeles, San Francisco, dan lain-lain (Lim \& Yoo, 2012). Namun, sejauh ini masih sedikit studi atau penelitian yang menyatakan bahwa situs web telah berperan sebagai atribut pendukung destinasi di Indonesia.

Menyadari betapa pentingnya situs web Wonderful Indonesia, maka evaluasi terhadap situs web tersebut sudah selayaknya untuk dilakukan. Di samping dalam rangka mengetahui sudah sejauh mana perkembangannya, evaluasi juga dapat dijadikan masukan kepada pihak pengembang. Oleh karena itu, muncul pemikiran untuk mengevaluasi situs web ini berdasarkan model yang biasa digunakan dalam kasus evaluasi situs web DMO, dimana model ini merupakan hasil pemikiran dari Li \& Wang tahun 2010, yaitu model ICTRT (Information, Communication, Transaction, Relationship, Technical-Merit). Idealnya, situs web yang yang baik adalah situs yang informatif, komunikatif, handal dalam setiap transaksinya, mampu berhubungan dengan konsumennya atau penggunanya secara interaktif, serta handal secara teknis (Benckendorff dkk., 2014).

Mengingat pentingnya evaluasi tersebut, maka pemilihan responden didasarkan pada pengalamannya (experience) dalam hal akses informasi pariwisata. Ada tiga pilihan responden yang memungkinkan, yaitu pemerintah, praktisi dan akademi pariwisata. Namun, dalam kasus ini 
praktisi pariwisata dijadikan sebagai sampel penelitian. Dengan pertimbangan bahwa praktisi pariwisata merupakan pihak perantara (intermediate), yang notabene sudah terbiasa dalam menjembatani kepentingan informasi dari suatu destinasi pariwisata hingga sampai ke konsumen, maka diputuskan bahwa penelitian ini dilakukan dengan melibatkan praktisi pariwisata sebagai respondennya. Selain itu, wawancara terhadap perwakilan stakeholder, mulai dari pemerintah, praktisi, dan akademisi juga dilakukan supaya menemukan kesesuaian terhadap rekomendasi yang nantinya bisa dijadikan pedoman untuk penyusunan rencana pengembangan situs web Wonderful Indonesia ke depannya.

\section{Penelitian tentang Teknologi Informasi Pariwisata}

Sejauh ini, ada banyak studi yang menunjukkan betapa eratnya hubungan antara TI dengan pariwisata. Studi interdisiplin semacam ini ternyata mampu bersinergi antara satu dengan lainnya, di samping memang masih diperlukannya peneliti-peneliti yang kaya dengan pengetahuan multidisiplin ( $\mathrm{Li}$ dkk., 2013). Penelitian tentang sistem rekomendasi (Linaza dkk., 2011), social media (Magasic, 2016), location basedservice (Neuhofer, 2012), e-Destination (Buhalis \& Wagner, 2013), e-WOM (Marchiori dkk., 2013), teknologi bergerak/mobile technology (Groth \& Haslwanter, 2015), hingga smart tourism (Buhalis \& Amaranggana, 2014) merupakan beberapa contoh yang menunjukkan betapa pesatnya studi mengenai teknologi informasi dalam bidang pariwisata. Di Indonesia, salah satu studi yang berkaitan dengan permasalahan ini adalah analisis situs web Wonderful Indonesia sebagai sumber informasi pariwisata nasional (Dewantara, 2015).

Keberadaan internet telah mendorong pencarian informasi secara lebih cepat dan accessible, dimana nyaris segala macam informasi bisa ditemukan di dalamnya. Pencarian informasi secara daring (online) memiliki beberapa keuntungan, antara lain rendahnya biaya yang keluar, adanya kesesuaian terhadap informasi, mudah dalam membandingkan/komparasi satu produk dengan produk lainnya, interaktif, adanya komunitas virtual yang menunjang, dan akses penuh selama 24 jam (Wang dkk., 2002 dalam Ho dkk., 2012). Inilah yang menyebabkan mengapa pencarian via internet semakin banyak dilakukan sampai detik ini, di samping memang makin berkembangnya infrastruktur jaringan (network), mulai dari frekuensi jaringan 3G, 4G, bahkan sampai 5G. Segala bentuk aktivitas yang terjadi dalam dunia internet semakin meluas, tidak hanya terpaku pada pencarian informasi saja, melainkan juga hal-hal lain yang mendorong orang-orang saling berlomba-lomba untuk mempromosikan (promoting) atau membagikan (sharing) informasi tersebut. Era digital seperti saat ini memungkinkan setiap penggunanya untuk berkreasi dengan bantuan teknologi.

Secara umum, pariwisata pada hakikatnya dapat dikatakan sebagai information-based phenomenon. Inilah mengapa di era digital seperti sekarang ini sumber-sumber informasi pariwisata menjadi penting. Kebutuhan akan informasi telah mendorong situs web sebagai salah satu teknologi yang bisa diandalkan. Situs web dapat dikatakan handal karena sifatnya yang multiplatform, alias bisa berjalan pada berbagai macam sistem operasi dan 
device. Hal ini didukung dengan perkembangan internet sebagai rich environment yang berisikan berbagai macam informasi dan sumber daya, sehingga menyebabkan wisatawan menggunakannya untuk menelusuri situs web, menemukan sesuatu yang menarik, mencari topik tertentu, serta mengambil informasi yang relevan. Kebanyakan wisatawan mengambil informasi dari berbagai sumber informasi di situs web, sehingga menjadi penting untuk menentukan perbedaan dalam sumbersumber informasi tersebut serta identifikasi karakteristik atau sifat dari setiap sumber untuk memahami kebutuhan maupun kecenderungan wisatawan (No \& Kim, 2015).

Berbicara mengenai situs web pariwisata nasional, situs web Wonderful Indonesia termasuk dalam kategori public website, karena situs web ini merupakan situs web resmi milik Kementerian Pariwisata Republik Indonesia. Jika mengingat kembali mengenai potensi kemajuan teknologi informasi, maka perlu dilihat lagi apakah kinerja situs web ini sudah mampu mewakili sumber informasi pariwisata tanah air. Salah satu riset yang sudah dilakukan terkait permasalahan ini adalah mengenai konten situs web Wonderful Indonesia. Situs web ini perlu melakukan perbaikan terhadap halaman depan (homepage), konten about Indonesia, konten discover Indonesia, dan konten perencanaan liburan ke Indonesia (Dewantara, 2015). Namun, pendekatan yang dilakukan pada penelitian ini masih belum lengkap, terlebih jika hendak melakukan perbaikan terhadap situs web. Oleh karena itu, evaluasi yang lebih mendalam terhadap konten situs web ini diperlukan sebagai tahap lanjut dari penelitian terkait situs web Wonderful Indonesia.

\section{Evaluasi Situs Web Pariwisata berdasarkan Model ICTRT}

Situs web pariwisata, dalam hal ini situs web DMO (Destination Management Organization) memegang peranan penting dalam kegiatan promosi dan manajemen destinasi dalam suatu negara (Benckendorff dkk., 2014). Itu artinya, situs web Wonderful Indonesia memegang peranan penting sebagai situs web DMO Indonesia, utamanya apabila dibandingkan dengan situs web pariwisata negara-negara ASEAN lainnya. Daftar situs web DMO dari negaranegara anggota ASEAN dapat dilihat pada tabel 1 berikut.

Tabel 1. Daftar Situs Web Pariwisata Negara-Negara ASEAN beserta tautan/link-nya

\begin{tabular}{|l|l|l|}
\hline No & Negara & Situs Web DMO (tautan/link) \\
\hline 1. & Kamboja & www.tourismcambodia.org \\
\hline 2. & Laos & - \\
\hline 3. & Myanmar & - \\
\hline 4. & Thailand & www.tourismthailand.org \\
\hline 5. & Vietnam & www.vietnamtourism.com \\
\hline 6. & Brunei & www.bruneitourism.travel \\
\hline 7. & $\begin{array}{l}\text { Filipina } \\
\text { 8. }\end{array}$ & $\begin{array}{l}\text { Malaysia } \\
\text { www.tourism.gov.ph }\end{array}$ \\
\hline 9. & $\begin{array}{c}\text { Singapura } \\
\text { www.malaysia.travel }\end{array}$ & visitsingapore.com \\
\hline 10. & $\begin{array}{l}\text { Timor } \\
\text { Leste }\end{array}$ & - \\
\hline 11. & $\begin{array}{l}\text { Indonesia } \\
\text { Sumber: www.aseantourism.travel (diakses }\end{array}$ & www.indonesia.travel \\
\hline
\end{tabular}

Berdasarkan tabel di atas, dapat dilihat bahwa hampir rata-rata semua negara anggota ASEAN telah memiliki situs web DMO, kecuali Laos, Myanmar, dan Timor Leste. Hal ini menunjukkan bahwa secara 
rata-rata negara-negara Asia Tenggara telah memiliki situs web pariwisata yang mampu memenuhi kebutuhan promosi dan manajemen destinasi. Tinggal sekarang bagaimana informasi yang terdapat di dalam situs web bisa sesuai dengan kebutuhan pengguna, khususnya stakeholders pariwisata.

Branding Indonesia di mata dunia mulai tertata semenjak munculnya slogan Wonderful Indonesia atau Pesona Indonesia pada tahun 2011. Pentingnya branding di samping turut mempopulerkan destinasi pariwisata Indonesia, melainkan juga untuk memicu minat yang lebih dalam tentang seperti apa Wonderful Indonesia yang dimaksud, terutama jika berbicara di era dengan perubahan yang serba cepat seperti sekarang ini. Branding tidak lagi dilakukan di dunia nyata saja, namun juga telah merambah menuju dunia maya. Selain luring (offline), branding juga bisa dilakukan secara daring (online). Demikian pula dengan penyebaran informasi pariwisata, apabila berbicara lebih spesifik tentang destinasi pariwisata yang ada. Salah satu media yang digunakan dalam kaitannya dengan penyebaran informasi tersebut adalah situs web. Oleh karena itu, penekanan tentang pentingnya situs web akan menjadi acuan dalam penelitian ini.

Situs web Wonderful Indonesia merupakan situs web DMO (Destination Management Organization) tingkat nasional, dimana situs web ini dapat dikategorikan sebagai NTO (National Tourism Organization). Untuk itu, evaluasi yang dilakukan pada situs web Wonderful Indonesia mengadaptasi evaluasi yang biasanya dilakukan pada situs web DMO, yaitu evaluasi situs web berdasarkan model ICTRT (Information, Communication, Transaction, Relationship, and Technical-merit).
Selanjutnya, evaluasi situs web ini dilakukan untuk mengetahui tingkat kepentingan (Importance) dan tingkat kinerjanya (Performance), dimana kedua variabel tersebut diukur berdasarkan indikator yang terdapat dalam model ICTRT. Terdapat 5 dimensi dalam model ICTRT, dimana ada total 48 indikator yang diturunkan dari masing-masing dimensi (Li \& Wang, 2010 dalam Mecha, Wiranatha, \& Sudiarta, 2019). Pada penelitian kali ini, Information atau dimensi informasi dijadikan tolok ukur dalam penyusunan rekomendasi. Adapun yang termasuk dalam dimensi informasi dapat dilihat pada tabel di bawah ini.

Tabel 2. Dimensi Informasi pada Model ICTRT

\begin{tabular}{|c|c|c|}
\hline \multirow{13}{*}{$\begin{array}{c}\text { Dimensi } \\
\text { Informasi } \\
\text { (total }=18 \text { ) }\end{array}$} & 1. & $\begin{array}{l}\text { Informasi daya tarik wisata } \\
\text { (Attraction information) }\end{array}$ \\
\hline & 2. & $\begin{array}{l}\text { Informasi aktivitas wisata } \\
\text { (Activities information) }\end{array}$ \\
\hline & 3. & $\begin{array}{l}\text { Peta dan petunjuk arah } \\
\text { (Maps and directions) }\end{array}$ \\
\hline & 4. & $\begin{array}{l}\text { Informasi latar belakang } \\
\text { destinasi } \\
\text { (Destination background } \\
\text { information) }\end{array}$ \\
\hline & 5. & $\begin{array}{l}\text { Produk tema } \\
\text { (Themed products) }\end{array}$ \\
\hline & 6. & $\begin{array}{l}\text { Informasi transportasi } \\
\text { (Transportation } \\
\text { information) }\end{array}$ \\
\hline & 7. & $\begin{array}{l}\text { Kalendar event } \\
\text { (Events calendar) }\end{array}$ \\
\hline & 8. & $\begin{array}{l}\text { Informasi restoran } \\
\text { (Restaurant information) }\end{array}$ \\
\hline & 9. & $\begin{array}{l}\text { Panduan wisata/brosur } \\
\text { (Travel guides/brochures) }\end{array}$ \\
\hline & 10. & $\begin{array}{l}\text { Agen wisata } \\
\text { (Travel agents) }\end{array}$ \\
\hline & 11. & $\begin{array}{l}\text { Informasi akomodasi } \\
\text { (Accommodation } \\
\text { information) }\end{array}$ \\
\hline & 12. & $\begin{array}{l}\text { Paket perjalanan wisata } \\
\text { (Travel packages) }\end{array}$ \\
\hline & 13. & $\begin{array}{l}\text { Informasi hiburan } \\
\text { (Entertainment } \\
\text { information) }\end{array}$ \\
\hline
\end{tabular}




\begin{tabular}{|c|c|l|}
\hline & 14. & $\begin{array}{l}\text { Informasi cuaca lokal } \\
\text { (Local weather } \\
\text { information) }\end{array}$ \\
\cline { 2 - 3 } & 15. & $\begin{array}{l}\text { Informasi belanja } \\
\text { (Shopping information) }\end{array}$ \\
\cline { 2 - 3 } 16. & $\begin{array}{l}\text { Tips perjalanan wisata } \\
\text { (Travel tips) }\end{array}$ \\
\cline { 2 - 3 } 17. & $\begin{array}{l}\text { Perencana perjalanan } \\
\text { wisata/liburan } \\
\text { (Trip/vacation planner) }\end{array}$ \\
\cline { 2 - 3 } 18. & $\begin{array}{l}\text { Terhubung dengan laman } \\
\text { daerah/kota/area } \\
\text { (Linked to } \\
\text { regional/city/area pages) }\end{array}$ \\
\hline
\end{tabular}

Sumber: Li \& Wang, 2010

\section{Metode}

Studi ini dihimpun berdasarkan penelitian yang telah dilakukan sebelumnya, yaitu mengenai evaluasi situs web Wonderful Indonesia berdasarkan model ICTRT (Mecha, Wiranatha, \& Sudiarta, 2019). Model ICTRT yang terdiri dari dimensi Information, Communication, Transaction, Relationship, and Technicalmerit merupakan salah satu landasan yang biasa digunakan untuk evaluasi suatu situs web DMO, dimana dalam kasus ini penekannya difokuskan pada Information atau dimensi informasinya.

Dimensi informasi pada model ICTRT terdiri atas 18 indikator, seperti yang tertera pada tabel 2. Indikator-indikator tersebut diterjemahkan ke dalam kuesioner dan dipetakan dengan skala Likert rentang 1-5. Kemudian, IPA (Important-Performance Analysis) digunakan sebagai analysis tool dalam menentukan rekomendasinya.

Rekomendasi disusun berdasarkan indikator-indikator dimensi informasi pada kuadran I grafik IPA. Kuadran I menunjukkan indikator-indikator mana saja pada situs web Wonderful Indonesia yang perlu untuk diperhatikan (Concentrate Here).
Penentuan sampel pada studi tersebut dilakukan terhadap biro perjalanan wisata (travel agent) yang tergabung dalam organisasi ASITA (Association of Indonesia Tours and Travel Agencies) Bali. ASITA yang menaungi biro perjalanan wisata dianggap representasi dari praktisi pariwisata, mengingat bahwa situs web Wonderful Indonesia merupakan media perantara (intermediaries) antara biro perjalanan wisata (supply) kepada wisatawan (demand). Terdapat total 80 biro perjalanan wisata (travel agent) yang dijadikan sampel penelitian, dimana mereka mengisi kuesioner yang dibreakdown berdasarkan dimensi informasi di atas.

Hasil evaluasi ini disusun berdasarkan grafik IPA yang terdapat pada kuadran I. Ada 2 indikator yang termasuk di dalam sini, yaitu informasi akomodasi (accommodation information) dan informasi cuaca local (local weather information). Indikator-indikator yang berasal dari dimensi informasi ini merupakan bagian yang harus diperhatikan dalam pengembangan situs web Wonderful Indonesia ke depannya. Oleh karena itu, di samping adanya sampling terhadap praktisi pariwisata, dalam hal ini biro perjalanan wisata (ASITA Bali), dilakukan pula wawancara terhadap para pakar yang berasal dari stakeholders, yaitu pemerintah, akademisi, serta praktisi pariwisata itu sendiri. Wawancara (interview) ini bertujuan sebagai bagian dari cross check terhadap hasil evaluasi yang telah dilakukan sebelumnya. Sehingga, hasil evaluasi nantinya bisa sesuai dengan pandangan para pakar, dimana diharapkan mampu mewakili pandangan pengguna informasi pariwisata secara umum. 


\section{Hasil dan Pembahasan}

Wawancara terhadap para stakeholder pariwisata, yaitu pemerintah, akademisi, serta praktisi mengacu pada pertimbangan bahwa dalam kasus ini situs web Wonderful Indonesia adalah situs web resmi milik pemerintah (Kementerian Pariwisata). Praktisi pariwisata, yaitu biro perjalanan wisata yang tergabung dalam ASITA regional Bali dapat dikatakan sebagai perwakilan dari seluruh populasi praktisi pariwisata Indonesia. Kemudian, tidak lupa peran akademisi sebagai jembatan penghubung antara kepentingan pemerintah dan praktisi, dimana penelitian ini juga nantinya dapat menjadi landasan dalam pengembangan situs web pariwisata, khususnya situs web Wonderful Indonesia.

Pakar yang berasal dari pemerintah adalah salah seorang pegawai negeri sipil (PNS) Deputi Bidang Pengembangan Pemasaran I Kementerian Pariwisata Indonesia, Dewa Putu Bagus Pujawan Putra, S.Par., M.Par. Kemudian, pakar yang berasal dari akademisi adalah guru besar bidang Teknologi Informasi Universitas Udayana, Prof. Dr. I Ketut Gede Darma Putra, S.Kom., M.T. Terakhir, pakar yang berasal dari kalangan praktisi adalah ketua Association of Indonesian Tours and Travel Agencies (ASITA) Bali, Ketut Ardana, S.H. Beliau semua ini diwawancarai di tempat dan waktu yang berbeda, dan diberikan pertanyaan seputar situs web Wonderful Indonesia, dengan penekanan terhadap indikator yang perlu diperhatikan sesuai hasil evaluasi.

Dengan melihat hasil yang terdapat pada kuadran I, maka diperlukan adanya perhatian terhadap indikator dimensi informasi (Information), yaitu informasi cuaca lokal (local weather information) dan informasi akomodasi (accommodation information). Informasi cuaca lokal seyogianya bisa disesuaikan dengan informasi cuaca per daerah, dimana artinya adalah paling tidak ada total 34 informasi cuaca lokal yang mewakili setiap provinsi di Indonesia. Informasi cuaca lokal ini akan lebih akurat jika disertai dengan prakiraan cuaca, sehingga pengguna bisa mengetahui lebih awal mengenai kondisi cuaca yang sekiranya akan terjadi. Atribut penting yang wajib ada di dalam informasi cuaca lokal antara lain suhu (temperature), nama lokasi (daerah/provinsi), dan keterangan cuaca (cerah, berawan, dan lain sebagainya).

Informasi cuaca lokal merupakan informasi penting yang wajib ada dalam situs web Wonderful Indonesia. Menurut pandangan Ketua Asosiasi Biro Perjalanan Wisata se-Bali (ASITA Bali), Ketut Ardana, S.H., pihaknya kerap mendapat pertanyaan-pertanyaan singkat mengenai bagaimana kondisi cuaca terkini dari suatu destinasidestinasi Nusantara (Petikan Wawancara, 06 Juni 2018). Hal tersebut mengingat betapa luasnya wilayah kepulauan Indonesia, dimana ini berkontribusi besar terhadap variasi cuaca lokal yang ada di dalamnya. Untuk itu, salah satu pengembangan yang bisa dilakukan adalah dengan membangun fitur cuaca lokal ini dengan bantuan web service dan ditampilkan dengan pop-up yang tentunya disesuaikan dengan lokasi destinasi pariwisata. Untuk awal, fitur dapat diujicobakan terlebih dahulu pada daerah provinsi, sebelum nantinya berkembang ke kota/kabupaten yang lebih spesifik.

Kemudian, informasi akomodasi mencakup segala informasi mengenai hotel, penginapan, villa, maupun guest house yang berkaitan erat dengan 
tempat menginap sementara bagi pengunjung atau wisatawan. Itu artinya, akomodasi memegang peranan penting dalam pariwisata, apalagi jika mengingat bahwa akomodasi (accomodation) adalah salah satu bagian dari kerangka pembentuk destinasi pariwisata yang tergabung dalam konsep 6A. Konsep 6A tersebut terdiri dari: (1) attractions, (2) accessibility, (3) amenities, (4) available packages, (5) activities, dan (6) ancillary services, dimana akomodasi itu sendiri merupakan bagian dari amenities (Buhalis, 2000). Dengan demikian, perlu adanya penambahan terhadap fitur pencarian hotel atau penginapan dalam situs web Wonderful Indonesia. Namun, yang lebih penting adalah bagaimana informasi akomodasi bisa dispesifikasikan sesuai dengan kategorinya, karena akomodasi sangat beragam tipe dan macamnya.

Hal ini senada dengan yang diungkap oleh pegawai negeri sipil Deputi Bidang Pengembangan Pemasaran I Kementerian Pariwisata Indonesia, Dewa Putu Bagus Pujawan Putra. Informasi akomodasi sudah mampu ditampilkan ke dengan baik, walaupun informasinya masih tumpang tindih dengan informasi paket wisata (packages). Memang betul bahwa informasi akomodasi perlu dispesifikasikan dengan kategorinya (misalnya hotel bintang 1, 2, dan lain sebagainya), dan jika memungkinkan ada range harga yang bisa ditampilkan, mengingat bahwa perkara harga (fixed price) tentunya adalah urusan bisnis dari pihak yang bersangkutan. Sekalipun informasi akomodasi sudah mendapat ruang pada situs web lain yang lebih spesifik, namun tetap dibutuhkan adanya gambaran singkat mengenai akomodasi apa saja yang terdapat dalam suatu destinasi. Apalagi, situs web Wonderful Indonesia mempunyai peran penting sebagai sumber informasi berskala nasional, serta perlu diingat bahwa informasi akomodasi merupakan komponen penting dari suatu destinasi pariwisata.

Tambahan lain adalah tentang apa yang diungkapkan oleh Prof. I Ketut Gede Darma Putra, guru besar bidang Teknologi Informasi Universitas Udayana. Beliau bertutur mengenai tur virtual, yang notabene merupakan fitur yang bersifat teknis (Petikan Wawancara, 07 Juni 2018). Tur virtual ini merupakan fitur yang cukup penting, dalam artian jika hendak dikembangkan maka diperlukan dukungan dan usaha yang tidak sedikit. Namun, perlu diingat bahwa secara umum situs web Wonderful Indonesia lebih condong pada pengembangan strategis dibandingkan pengembangan teknis. Oleh karena itu, semasih tur virtual via $360^{\circ}$ view telah dijalankan, maka selanjutnya adalah bagaimana seluruh destinasi, khususnya daya tarik wisata di seluruh Nusantara bisa ditampilkan dengan $360^{\circ}$ view. Bagian strategisnya adalah bagaimana seluruh informasi destinasi mampu sampai ke konsumen pariwisata secara global, dan kepentingan antar stakeholders, baik pemerintah, praktisi, maupun akademisi tetap terjaga dengan baik.

\section{Simpulan}

Rencana pengembangan situs web Wonderful Indonesia nantinya diharapkan disusun sesuai dengan indikator hasil evaluasi pada dimensi informasi (Information), yaitu informasi hotel atau penginapan (accomodation information) dan informasi cuaca (local weather information). Diperlukan adanya pembaruan berkala (update) agar setiap informasi yang terdapat di dalam situs web Wonderful Indonesia sesuai dengan kenyataannya serta dapat dipercaya 
kebenarannya, terutama dalam informasi Destinations, mengingat peluang masih banyaknya destinasidestinasi baru yang potensial. Secara garis besar, pengembangan yang dilakukan hendaknya agar disesuaikan dengan kebutuhan informasi pengguna, khususnya wisatawan sebagai pengguna utamanya (end user).

\section{Daftar Pustaka}

Benckendorff, P. J., Sheldon, P. J., \& Fesenmaier, D. R. (2014). Tourism Information Technology, 2nd Edition (2nd ed.). Boston, MA: CABI.

Buhalis, D. (2000). Marketing the competitive destination of the future. Tourism Management, 21, 97-116.

Buhalis, D., \& Amaranggana, A. (2014). Smart Tourism Destination. Information and Communication Technologies in Tourism 2014 (pp. 553-564). Dublin, Ireland: Springer.

Buhalis, D., \& Law, R. (2008). Progress in information technology and tourism management: 20 years on and 10 years after the internet: The state of eTourism research. Tourism Management, 29, 609623.

Buhalis, D., \& Wagner, R. (2013). Edestinations: Global Best Practice in Tourism Technologies and Applications. Information and Communication Technologies in Tourism 2013 (pp. 119-130). Innsbruck, Austria: Springer.

Dewantara, M. H. (2015). ANALISIS DAN PENGEMBANGAN SITUS RESMI PARIWISATA INDONESIA DAN SISTEM INFORMASI PENDUKUNGNYA. Jurnal Master Pariwisata , 1(2), 9-24.
Groth, A., \& Haslwanter, D. (2015). Perceived Usability, Attractiveness and Intuitiveness of Responsive Mobile Tourism Websites: A User Experience Study. Information and Communication Technologies in Tourism 2015 (pp. 593-606). Lugano, Switzerland: Springer.

Ho, C.-I., Lin, M.-H., \& Chen, H.-M. (2012). Web users' behavioural patterns of tourism information search: From online to offline. Information and Communication Technologies in Tourism 2012 (pp. 1468-1482). Helsingborg, Sweden: Springer.

Li, N., Buhalis, D., \& Zhang, L. (2013). Interdisciplinary Research on Information Science and Tourism. Information and Communication Technologies in Tourism 2013 (pp. 302-313). Innsbruck, Austria: Springer.

Lim, Y. S., \& Yoo, E. E. (2012). TripAdvisor.com vs. NYCGO.com: Evaluation of Functional Components of Generalist and Specialist Tourism Websites. Information and Communication Technologies in Tourism 2012 (pp. 120-131). Helsingborg, Sweden: Springer.

Linaza, M. T., Agirregoikoa, A., Garcia, A., Torres, J. I., \& Aranburu, K. (2011). Image-based Travel Recommender System for small tourist destinations. Information and Communication Technologies in Tourism 2011 (pp. 1-12). Innsbruck, Austria: Springer.

Lytras, M., Pablos, P. O., Damiani, E., \& Dias, L. (2010). Digital Culture and E-Tourism (Technologies, Applications and Management Approaches) (1st ed.). USA: IGI Global. 
Magasic, M. (2016). The 'Selfie Gaze' and 'Social Media Pilgrimage': Two Frames for Conceptualising the Experience of Social Media Using Tourists. Information and Communication Technologies in Tourism 2016 (pp. 173-182). Bilbao, Spain: Springer.

Marchiori, E., Milwood, P., \& Zach, F. (2013). Drivers and Benefits of Analysing DMOs' eWOM Activities. Information and Communication Technologies in Tourism 2013 (pp. 107-118). Innsbruck, Austria: Springer.

Mecha, I. P., Wiranatha, A. S., \& Sudiarta, I. N. (2019). EVALUASI SITUS WEB PARIWISATA WONDERFUL INDONESIA BERDASARKAN MODEL ICTRT (INFORMATION, COMMUNICATION, TRANSACTION, RELATIONSHIP, AND TECHNICAL-MERIT). Jurnal Master Pariwisata, 5(2), 241-258.

Neuhofer, B. (2012). An Analysis of the Perceived Value of Touristic Location Based Services. Information and Communication Technologies in Tourism 2012 (pp. 84-95). Helsingborg, Sweden: Springer.

No, E., \& Kim, J. K. (2015). Comparing the attributes of online tourism information sources. Computers in Human Behavior, 50, 564-575.

Sung, T. K. (2018). Industry 4.0: A Korea perspective. Technological Forecasting \& Social Change, 132, 40-45.

Yannacopoulos, D., Manolitzas, P., Matsatsinis, N., \& Grigoroudis, E. (2014). Evaluating Websites and Web Services: Interdisciplinary Perspectives on User Satisfaction (1st ed.). United States of America: IGI Global. 